本文引用格式 / Please cite this article as:

Han, Y. W. Zhang, S. \& Yin, L. H. (2019). Quantifying the Carbon Storage Capacity and Its Spatial Distribution Patterns of Green Spaces in A Metropolitan Area: A Case Study of Seoul, South Korea. Landscape Architecture Frontiers, 7(2), 55-65. https://doi.org/10.15302/J-LAF-20190205

\section{大都市区绿地碳储存能力 \\ 及其空间分布特点探究: \\ 以韩国首尔市为例 \\ QUANTIFYING THE \\ CARBON STORAGE CAPACITY \\ AND ITS SPATIAL \\ DISTRIBUTION PATTERNS \\ OF GREEN SPACES IN A \\ METROPOLITAN AREA: \\ A CASE STUDY OF SEOUL, SOUTH KOREA}

1 概述

气候变化是人类面临的重要环境议题之一, 相关研究对城市范围 内绿地的二氧化碳消减作用多有讨论 ${ }^{[1]}$ 。绿地 (Green Spaces, 也多译作 “绿色空间” ${ }^{[2]}$ ) 作为城市中主要的生境类型, 为城市提供了一系列生态 系统服务功能[3]。其中, 绿地的碳储存功能对于缓解城市热岛效应、调 节局地小气候，以及维持城市碳氧平衡和生态平衡发挥着重要作用 ${ }^{[4]}$

https://doi.org/10.15302/J-LAF-20190205 收稿时间 RECEIVED DATE / 2019-01-07 中图分类号/ X821 文献标识码/A

韩依纹

华中科技大学建筑与城市规划学院景观系讲师

张舒

华中科技大学建筑与城市规划学院景观系本科在读

殷利华

华中科技大学建筑与城市规划学院景观系副教授

大通讯作者

地址：湖北省武汉市洪山区华中科技大学建筑与城市规划学院南 四楼 401 室

邮编: 430074

摘要

绿地作为城市重要的生境类型可提供诸多生 态系统服务功能。其中, 绿地的碳储存功能可有 效减缓温室效应，这在全球气候变暖的背景下显 得尤为重要。由于精细化的空间数据通常较难获 取, 已有研究往往粗略地将绿地归纳为几种土地 利用类型以计算其碳储存量。然而, 由于绿地内 植被群落特点不同, 其碳储存能力也有所差别。 本文以韩国首尔市为例，旨在探索城市中多种绿 地类型的碳储存能力及其空间分布特点。基于 2005年和2015年首尔市的高精度生境数据, 本 研究归纳了17种目标绿地类型, 运用InVESTCarbon模型对其碳储量进行估算,可视化定量绿 地的碳储存量并明确其内部群落碳储存能力的空 间分布规律。本研究不仅可为首尔市及其他类似 区域的生态保护实践和可持续土地规划与管理提 供科学依据, 也可为我国城市生态系统服务功能 评估和绿地更新策略的制定提供借鉴。

关键词

绿地; 生态系统服务; 碳储存; 生境; InVEST 模型；热点；空间分布

基金项目:

国家自然科学基金项目“桥阴海绵体空间形态及景观绩效研究” ( 编号: 51678260 )

Research Fund:

hon the Spatial Form of Sponge Unit under Urban Viaduct and Its Landscape Performance, National Natural Science Foundation of China (No. 51678260)

编辑 田晓劼 翻译 田晓劼 萨拉·雅各布斯

EDITED TIAN Xiaojie TRANSLATEd BY TIAN Xiaojie Sara JACOBS

HAN Yiwen

Assistant Professor, Department of Landscape Architecture, School of Architecture and Urban Planning, Huazhong University of Science and Technology

ZHANG Shu

Undergraduate in the Department of Landscape Architecture, School of Architecture and Urban Planning, Huazhong University of Science and Technology

YIN Lihua

Associate Professor, Department of Landscape Architecture, School of Architecture and Urban Planning, Huazhong University of Science and Technology

\section{ABSTRACT}

As a significant habitat type in cities, green spaces can provide various ecosystem services. Among them the carbon storage of green spaces would effectively alleviate greenhouse effect, which is particularly important under the global warming. Due to difficulities in accessing high-resolution spatial data previous research has summarized green spaces into different land use types to calculate carbon storage. However, since different vegetation communities have different characteristics, carbon storage capacities of green spaces vary. Focusing on the Seoul City, South Korea, this research aims at exploring the carbon storage capacities of varied green spaces and its distribution patterns. Based on the highresolution habitat data of Seoul City in 2005 and 2015 the Integrated Valuation of Ecosystem Services and Tradeoffs (InVEST) model is used to estimate and visualize the carbon storage capacities of 17 types of green spaces to reveal the distribution patterns of carbon storage of different communities in the city's green spaces. This study not only provides a scientific basis for ecological protection practices and sustainable land planning and management in Seoul and other similar regions, but also offers a reference for urban ecosystem service assessment and green space renewal strategy development in China.

\section{KEYWORDS}

Green Spaces; Ecosystem Services; Carbon Storage; Habitat; InVEST Model; Hotspot; Spatial Distribution 
绿地碳储存能力的探究方法具有尺度差异性。中小尺度的碳储存 量估算往往通过野外调查和仪器测量完成, 例如哈亚特 - 奥博拉希姆 等 ${ }^{[5]}$ 通过样方调查和数理统计方法对欧洲栓皮栋 (Quercus suber) 林的 碳储存量进行了探究; 张景群等 ${ }^{[6]}$ 通过乔木样品采集, 灌木、草本和 地表凋落物调查, 以及土壤采样等方法测定了黄土高原刺槐 (Robinia pseudoacacia ) 林的碳储存量; 王立 ${ }^{[7]}$ 运用实地仪器测定、生物量法、 铬酸钾一水合加热法和样方调查等方法测算了重庆市主城区常见园林 树种及群落的碳储存能力。大尺度的碳储存量估算和土地类型关系较 大, 通常基于遥感平台并采用模型模拟的方法进行测算。由于精细化 分类的空间数据通常较难获取, 已有研究往往粗略地按照绿地所属的 土地利用类型来估算其碳储存量和社会价值 ${ }^{[8]}$, 例如, 何春阳等 ${ }^{[9]}$ 基 于土地利用数据将北京市内的绿地归类为农田、林地和草地, 并运 用InVEST模型探究了碳储存量的历史变化特点; 虎帅等 ${ }^{[10]}$ 亦基于土 地利用数据并运用InVEST模型测算了重庆市建设用地扩张进程中的 碳储存量变化。然而, 鉴于绿地内不同植被群落的碳储存能力不同 以及同种类型的绿地间的碳储存能力差异, 精细化分类的数据更有 利于分析特定绿地类型的特点及其生态系统功能。目前也有学者开 展了相关研究, 例如, 佐依 $\cdot G \cdot$ 戴维斯等 ${ }^{[11]}$ 通过对英国莱斯特市城 区的植被进行调查, 研究了典型的地面碳储存量和空间模式, 发现 庭院植栽与草本植被的碳储存能力相当, 此外, 公共绿地承担了主 要的城市碳储存功能; E - 格雷戈里 $\cdot$ 麦克弗森 ${ }^{[12]}$ 量化了美国加利福

\section{Introduction}

Climate change is one of the most pressing environmental problems facing human beings. Relevant research has discussed at length the role of green spaces in reducing urban carbon dioxide $^{[1]}$. As a main habitat type in urban areas, green spaces ${ }^{[2]}$ provide a wealth of ecosystem services ${ }^{[3]}$. For example, carbon storage would help alleviate urban heat island effect, regulate micoclimate, and maintain carbon-oxygen equilibriums and ecological balance in cities ${ }^{[4]}$.

Methods for exploring carbon storage capacity of green spaces are different at various scales. Carbon storage estimations of medium- or micro-scaled green spaces are generally done through field surveys and instrumental measurements. For example, Hayat Oubrahim et al. ${ }^{[5]}$ studied the carbon storage of cork oak (Quercus suber) forests through quadrat survey and mathematical statistics methods; Zhang Jingqun et al. ${ }^{[6]}$ measured the carbon storage of locust (Robinia pseudoacacia) forests on the Loess Plateau in China by collecting tree, shrub, herb, litter, and soil samples. Field instrument measurements, biomass methods, potassium chromate hydration heating methods, and quadrat survey methods were used by Wang $\mathrm{Li}^{[7]}$ to calculate the carbon storage capacity of common landscape trees and vegetation communities in the main urban area of Chongqing City, China. Large-scale carbon storage estimations are highly dependent on land use types and usually measured with remote sensing platforms and modeling simulation methods. Due to difficulities in accessing high-resolution spatial data, current research estimates the carbon storage capacity and social values of green scapes according to their land-use types ${ }^{[8]}$. For example, He Chunyang et al..$^{[9]}$ categorized green spaces in the city of Beijing as farmlands, woodlands, and grasslands and used the Integrated Valuation of Ecosystem Services and Tradeoffs (InVEST) model to examine the changing characteristics of carbon storage during different historical periods. Similarly, by studying land use data, Hu Shuai et al. ${ }^{[10]}$ employed the InVEST model to calculate carbon storage changes during urban sprawls in Chongqing City. However, given that in green spaces, carbon storage capacity of different vegetation communities varies, high-resolution data is needed for a refined study on the characteristics of a particular green space and its ecosystem role. For instance, Zoe G. Davies et al. ${ }^{[11]}$ studied the typical ground carbon storage capacity and spatial modes in urban area of Leicester, England and found that community gardens and herbaceous plants have shown comparable carbon storage capacities, and public green space plays a major role in urban carbon storage. E. Gregory McPherson ${ }^{[12]}$ quantified 
尼亚州城市森林在抵消人类碳排放方面的效益, 并提出了提升这些效 益的城市森林管理指南。尽管如此, 相关研究成果仍非常有限, 针对 不同地域及不同用地类型的案例研究仍需继续开展。

本研究基于韩国首尔市 2005 年和 2015 年高精度生境分类数据, 尝 试运用遥感工具和InVEST-Carbon模型进行分析，以探索城市绿地的碳 储存能力变化及碳储存量的空间分布特点。研究包括以下三个部分： 1 ）识别和归类首尔市现有绿地类型；2）评估2005年和2015年各类绿地 碳储存量及相关变化；3）探究碳储存量热点的空间分布特征。

\section{2 数据与方法}

\section{1 研究区域概况}

韩国首尔市位于朝鲜半岛中部（ $37^{\circ} 33^{\prime} \mathrm{N} ， 126^{\circ} 58^{\prime} \mathrm{E}$ ），面积 为 $605.18 \mathrm{~km}^{2}$, 属温带季风气候, 年平均气温 $12.5^{\circ} \mathrm{C}$, 年均降水量 $1451 \mathrm{~mm}^{\circledR}$ (图1 )。自20世纪70年代以来, 快速的城镇化进程使得这一 区域内的土地利用类型发生了巨大转变, 自然栖息地和城市生物多样

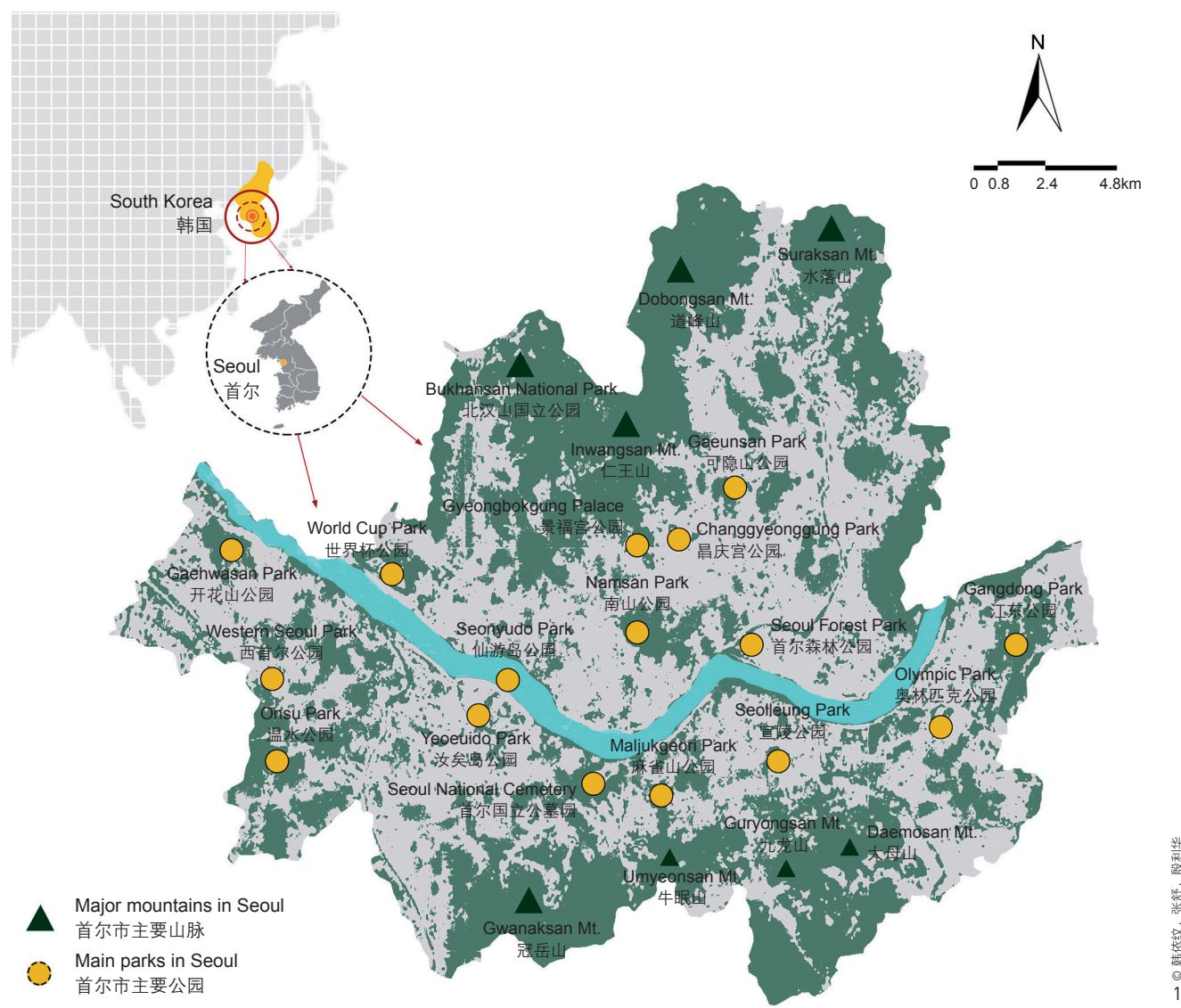

the benefits of urban forests in California in offsetting human carbon emissions and introduced guidelines for urban forest management to improve these benefits. However, such research results remain limited; additional case studies specific to different regions and varied land use types are expected.

With the high-resolution data of habitat classification of Seoul, South Korea in 2005 and 2015, this research employs remote sensing tools and InVEST-Carbon model to explore the changes of carbon storage capacity of the city and related spatial patterns. The study consists of three parts: 1 ) identifying and classifying land use types of existing green spaces in Seoul; 2 ) assessing the carbon storage of different green space types in 2005 and 2015, as well as their changes during 10 years; and, 3) exploring the distribution patterns of carbon storage hotspots.

\section{Data and Methods}

\subsection{Study Area}

Seoul City is located in the center of Korean Peninsula $\left(37^{\circ} 33^{\prime} \mathrm{N}, 126^{\circ} 58^{\prime} \mathrm{E}\right)$, covering an area of $605.18 \mathrm{~km}^{2}$. It has a temperate monsoon climate with an annual average temperature of $12.5^{\circ} \mathrm{C}$ and an annual mean precipitation of $1,451 \mathrm{~mm}^{(1)}$ (Fig. 1). Since the 1970s, rapid urbanization has 
性的减少是导致首尔市形成城市热岛的关键动因 ${ }^{[13]}$ 。为此, 首尔市 政府自1996年起致力于保护城市生态系统, 试图通过恢复遭到破坏 的自然生境来修复和加强其生态系统服务功能, 从而缓解诸多城市 环境问题 ${ }^{[14]}$ 。

\section{2 数据来源}

本文数据和来源:

1 ) 首尔市行政边界数据源自韩国政府平台;

2 ) 2005年和2015年的生境空间数据（Biotop Map）由首尔市政府 对高精度遥感图像和野外调查结果进行电子化后在线发布, 数据精度 为 $5 \mathrm{~m}$;

3 ) 模型模拟所用的碳密度数据通过参考相关文献及InVEST手册提 供的参考表确定。

\section{3 方法}

\subsection{1 绿地识别与分类}

首尔市政府建立的地理信息系统平台每年就植被群落、土地利 用等信息进行调查和等级指标统计, 之后以地图形式发布。通过利用 led to a dramatic shift in land use. The reduction of natural habitats and urban biodiversity has been considered as one of the key reasons of the occurrence of urban heat island ${ }^{[13]}$. Since 1996, the Seoul Metropolitan Government has devoted itself to protecting urban ecosystems and restoring ecosystem services by remediating damaged natural habitats to alleviate urban environmental problems ${ }^{[14]}$.

\subsection{Data Collecting}

Data in this paper is collected from:

1) The administrative boundary data of Seoul (the study area of this research) is derived from Korean governmental agencies;

2) Biotop maps of 2005 and 2015 published online by the Seoul Metropolitan Government that digitalized high-resolution (5-meter) remote sensing images and field survey results;

3) The carbon density data used in the modeling simulation of this research refers to previous literature and the InVEST manual.

\subsection{Methods}

2.3.1 Identification and Re-classification of Green Spaces

The geographic information system (GIS) platform established by the Seoul Metropolitan Government releases

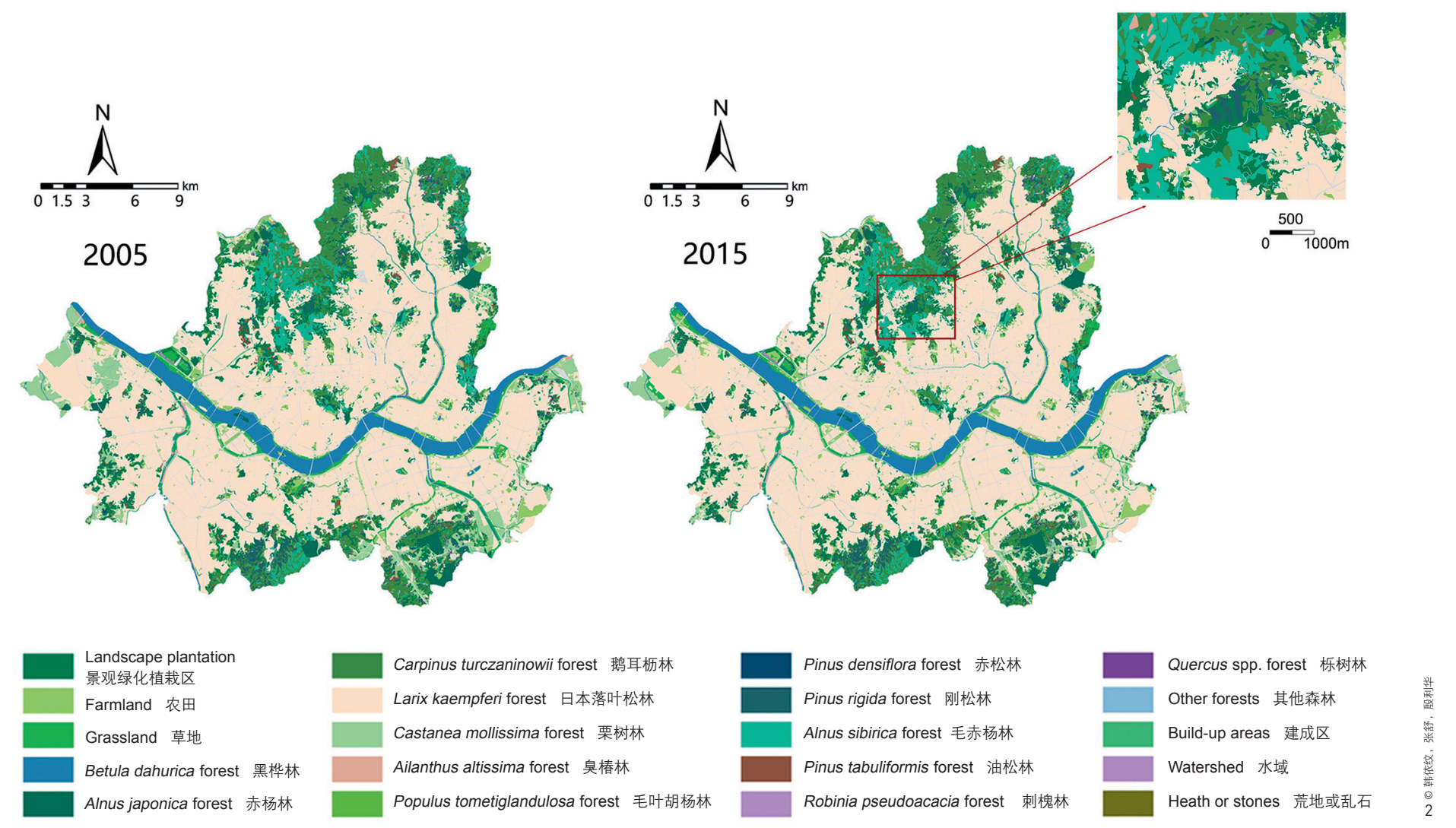

2. 2005 年和 2015 年生境数据
2. Habitat data in 2005 and 2015 
ArcGIS工具整合原始数据, 并根据研究目的重新归纳绿地类型, 本文 最终将绿地归纳为 17 类, 分别为景观绿化植栽区、农田、草地、黑桦 (Betula dahurica) 林、赤杨 (Alnus japonica) 林、我耳枥 (Carpinus turczaninowii) 林、日本落叶松 (Larix kaempferi) 林、栗树 (Castanea mollissima) 林、臭椿 (Ailanthus altissima) 林、毛叶胡杨 (Populus tomentiglandulosa) 林、赤松 (Pinus densiflora) 林、刚松 (Pinus rigida) 林、毛赤杨 (Alnus sibirica) 林、油松 (Pinus tabuliformis) 林、 刺槐（Robinia pseudoacacia）林、栋树（Quercus spp.）林，以及其他森 林 (图2)。

\subsection{2 碳储存空间叙述模型}

InVEST这一用于测算生态系统服务的模型由美国斯坦福大学主导 研发 ${ }^{[15]}$ 。其碳储存模块可用于估算地上、地下、土壤内和死亡有机物的 碳储存总量。地上部分碳密度指地表以上所有存活的植物材料 (如树 皮、树干、树枝和树叶) 单位面积上碳储存量的平均值; 地下部分碳 密度指地表以下植物活根系统单位面积上碳储存量的平均值; 土壤碳 密度是指矿质土壤和有机土壤单位面积上碳储存量的平均值 ${ }^{[16]}$; 死亡有 机物碳密度是指调落物和已死亡的地面留存树木等单位面积上碳储存 量的平均值。

总碳储存量模块计算公式为:

$$
\mathrm{C}=\mathrm{C}_{\text {above }}+\mathrm{C}_{\text {below }}+\mathrm{C}_{\text {soil }}+\mathrm{C}_{\text {dead }} \text {, }
$$

式中, $\mathrm{C}$ 表示碳总量（吨）; $\mathrm{C}_{\mathrm{above}}$ 表示地上部分的碳储存量; $\mathrm{C}_{\text {below }}$ 表示地下部分的碳储存量; $\mathrm{C}_{\mathrm{soi}}$ 表示土壤部分的碳储存量; $\mathrm{C}_{\text {dead }}$ 表示死 亡有机物的碳储存量。

由于首尔市全部绿地类型的碳密度数据较难获取, 本研究使用 的碳密度数据由已公开发表的国际文献中相似群落类型的碳密度数

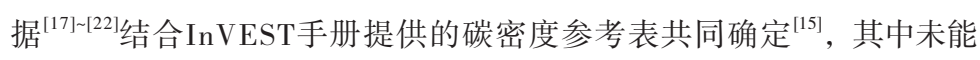
获取的碳库默认值为 0 , 最后InVEST模型可输出碳储存空间分布图。

\subsection{3 局部自相关分析方法一一热点分析}

通过将InVEST模型输出的碳储存空间分布图在ArcGIS平台上进 行热点分析, 可以探究绿地碳储存高值和低值在空间上发生聚类的位 survey information of vegetation community, land use, etc. annually, in form of maps with classification index. Integrating raw date by ArcGIS, this research reclassifies Seoul's green spaces into seventeen types: landscape plantation, farmland, grassland, Betula dahurica forest, Alnus japonica forest, Carpinus turczaninowii forest, Larix kaempferi forest, Castanea mollissima forest, Ailanthus altissima forest, Populus tomentiglandulosa forest, Pinus densiflora forest, Pinus rigida forest, Alnus sibirica forest, Pinus tabuliformis forest, Robinia pseudoacacia forest, Quercus spp. forest, and other forests (Fig. 2).

\subsubsection{Spatial Representation Model of Carbon Storage}

The InVEST model was developed by Stanford University to measure ecosystem services ${ }^{[15]}$. Its carbon storage module can be used to estimate the total carbon storage capacity of above-ground, underground, soil, and dead organics of a given area. Carbon density of above-ground refers to the average carbon storage capacity per unit of all organic parts of surviving plants above ground, such as barks, trunks, branches, and leaves; carbon density of underground is the average carbon storage capacity per unit of underground plant root systems; soil carbon density is the average carbon storage capacity per unit in mineral and organic soils ${ }^{[16]}$; and, dead organics carbon density is the average carbon storage capacity per unit of litters, dead trees, etc. remained on the ground.

In the InVEST model, the total carbon storage capacity of storage a given area is calculated as:

$$
\mathrm{C}=\mathrm{C}_{\text {above }}+\mathrm{C}_{\text {below }}+\mathrm{C}_{\text {soil }}+\mathrm{C}_{\text {dead }} \text {, }
$$

where $\mathrm{C}$ represents the total amount of carbon storage (tons); $\mathrm{C}_{\text {above }}, \mathrm{C}_{\text {below }}, \mathrm{C}_{\text {soil }}$, and $\mathrm{C}_{\text {dead }}$ represent above-ground carbon storage, underground carbon storage, soil carbon storage, and dead organics carbon storage, respectively.

Due to the lack of available carbon density data of each green space type in Seoul, the carbon density data used in this research refers to published carbon density research on similar community types globally ${ }^{[17] \sim 22]}$ and the carbon density reference table in the InVEST manual ${ }^{[15]}$. The unobtainable carbon pools are defaulted to zero. Finally, the InVEST model would output carbon storage distribution maps of the given study area.

\subsubsection{Local Autocorrelation Method for Hotspot Analysis}

This research analyzes the carbon storage distribution maps generated by the InVEST model with ArcGIS to examine the positions of spatial cluster of high- and low-carbon storage capacity by calculating the Getis-Ord $\mathrm{G}_{\mathrm{i}}^{*}$ statistic of each 
表1: 2005年和2015年间不同绿地类型面积变化

Table 1: Area changes of different green spaces between 2005 and 2015

\begin{tabular}{|c|c|c|}
\hline $\begin{array}{c}\text { 绿地类型 } \\
\text { Green sppaces types }\end{array}$ & $\begin{array}{l}\text { 2005年绿地面积 } \\
\text { Area in } 2005\left(\mathrm{hm}^{2}\right)\end{array}$ & $\begin{array}{r}2015 \text { 年绿地面积 } \\
\text { Area in } 2015\left(\mathrm{hm}^{2}\right)\end{array}$ \\
\hline $\begin{array}{c}\text { 景观绿化植栽区 } \\
\text { Landscape plantation }\end{array}$ & $2,383.10$ & $3,021.93$ \\
\hline $\begin{array}{l}\text { 农田 } \\
\text { Farmland }\end{array}$ & $2,984.51$ & $1,528.79$ \\
\hline $\begin{array}{l}\text { 草地 } \\
\text { Grassland }\end{array}$ & $1,462.34$ & $1,446.51$ \\
\hline $\begin{array}{c}\text { 黑桦林 } \\
\text { Betula dahurica forest }\end{array}$ & 17.70 & 16.49 \\
\hline $\begin{array}{c}\text { 赤杨林 } \\
\text { Alnus japonica forest }\end{array}$ & 14.21 & 13.78 \\
\hline $\begin{array}{c}\text { 鹅耳杤林 } \\
\text { Carpinus turczaninowii forest }\end{array}$ & 7.05 & 65.53 \\
\hline $\begin{array}{c}\text { 日本落叶松林 } \\
\text { Larix kaempferi forest }\end{array}$ & 42.87 & 44.91 \\
\hline $\begin{array}{c}\text { 栗树林 } \\
\text { Castanea mollissima forest }\end{array}$ & 214.75 & 188.45 \\
\hline $\begin{array}{c}\text { 臭椿林 } \\
\text { Ailanthus altissima forest }\end{array}$ & 20.11 & 21.19 \\
\hline $\begin{array}{c}\text { 毛叶胡杨林 } \\
\text { Populus tomentiglandulosa forest }\end{array}$ & 378.46 & 300.97 \\
\hline $\begin{array}{l}\text { 赤松林 } \\
\text { Pinus densiflora forest }\end{array}$ & 1976.49 & 1900.94 \\
\hline $\begin{array}{c}\text { 刚松林 } \\
\text { Pinus rigida forest }\end{array}$ & 1384.63 & 1332.89 \\
\hline $\begin{array}{c}\text { 毛赤杨林 } \\
\text { Alnus sibirica forest }\end{array}$ & 62.03 & 51.40 \\
\hline $\begin{array}{c}\text { 油松林 } \\
\text { Pinus tabuliformis forest }\end{array}$ & 267.53 & 252.30 \\
\hline $\begin{array}{c}\text { 刺槐林 } \\
\text { Robinia pseudoacacia forest }\end{array}$ & $3,435.31$ & $3,082.87$ \\
\hline $\begin{array}{c}\text { 栋树林 } \\
\text { Quercus spp. forest }\end{array}$ & $5,550.71$ & $5,418.03$ \\
\hline $\begin{array}{l}\text { 其他森林 } \\
\text { Other forests }\end{array}$ & $1,264.93$ & $1,197.02$ \\
\hline $\begin{array}{l}\text { 总计 } \\
\text { Total }\end{array}$ & $21,466.74$ & $19,883.99$ \\
\hline
\end{tabular}

置。热点分析计算一定范围内的所有要素的Getis-Ord $\mathrm{G}_{\mathrm{i}}{ }^{*}$ 统计值 ${ }^{[23][24]}$; 如果一个区域中某一要素值为高值且被同样高值的要素包围，则该位置 可以认为是统计学上的显著性热点。Getis-Ord $G_{i}{ }^{*}$ 计算公式为:

$$
G_{i}^{*}=\frac{\sqrt[s]{\frac{n \sum_{j=1}^{n} w_{i, j}^{2}-\left(\sum_{j=1}^{n} w_{i, j}\right)^{2}}{n-1}}}{\sqrt{\frac{X}{n} \sum_{j=1}^{n} w_{i, j}}},
$$

式中, $x_{j}$ 是要素 $j$ 的属性值, $w_{i, j}$ 表示要素 $i$ 和 $j$ 之间的空间权重, $\mathrm{n}$ 是 样本点总数, $\bar{X}$ 为均差, $\mathrm{S}$ 为标准差, $\mathrm{G}_{\mathrm{i}}{ }^{*}$ 的统计结果是样本点的得分结

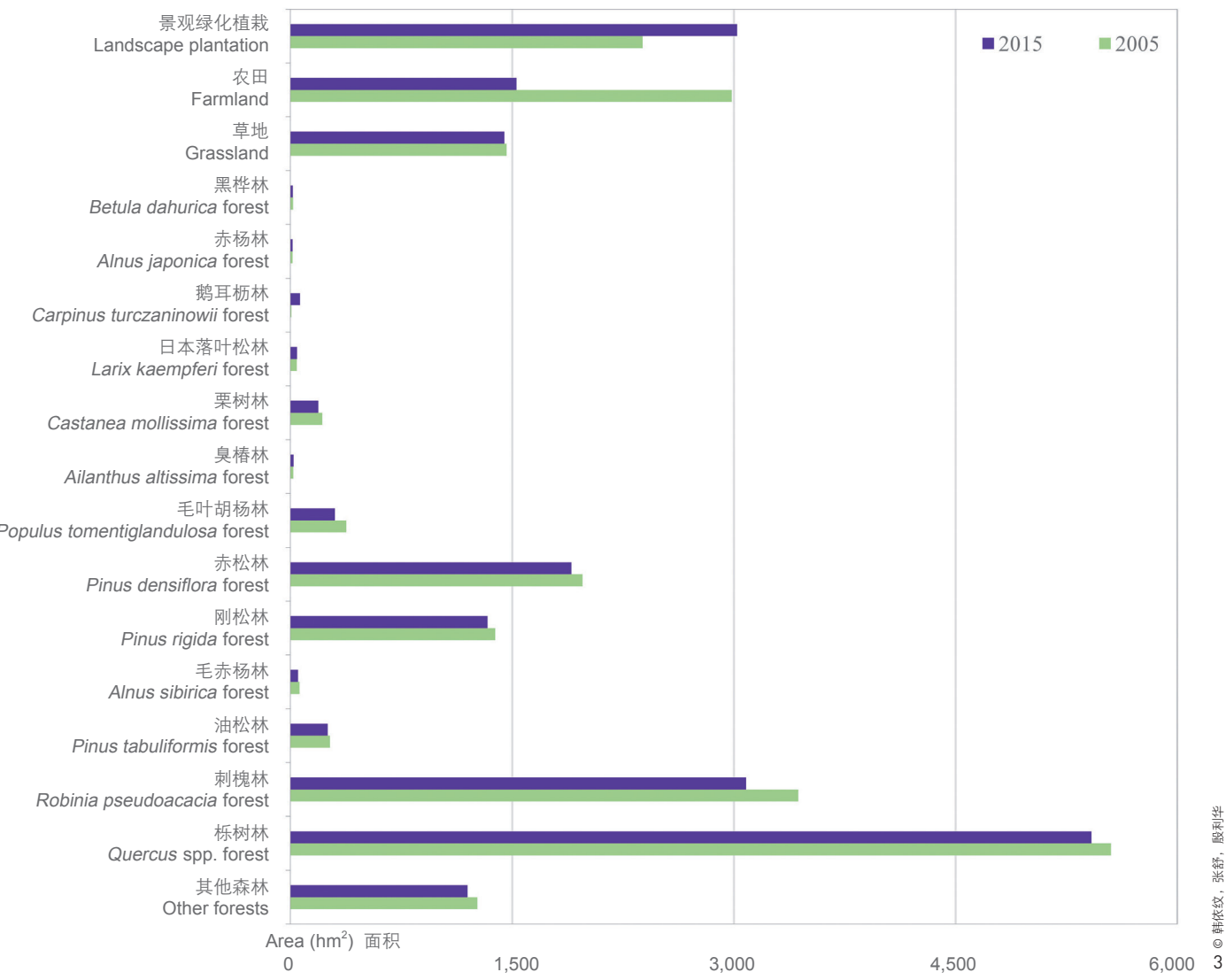

feature in the dataset ${ }^{[23][24]}$. If a feature will have a high value and be surrounded by other features with high values as well, it can be a statistically significant hotspot. The Getis-Ord $\mathrm{G}_{\mathrm{i}}{ }^{*}$ local statistic is given as

$$
G_{i}^{*}=\frac{\sum_{j=1}^{n} w_{i, j} x_{j}-\bar{X} \sum_{j=1}^{n} w_{i, j}}{\sqrt[s]{\frac{n \sum_{j=1}^{n} w_{i, j}^{2}-\left(\sum_{j=1}^{n} w_{i, j}\right)^{2}}{n-1}}},
$$

where, $x_{j}$ is the attribute value of feature $j, w_{i, j}$ indicates the spatial weight between feature $i$ and $j, \mathrm{n}$ is equal to total 
3. 2005 2015年间不同绿地 类型面积变化

2005 年和 2015 年各类生 境碳储存量分布图 (梛格 单元: $5 \mathrm{~m} \times 5 \mathrm{~m}$ )

3. Area changes of different green spaces between 2005 and 2015

4. Carbon storage distribution of various habitats in 2005 and 2015 Igrid unit: $5 \mathrm{~m} \times 5 \mathrm{ml}$

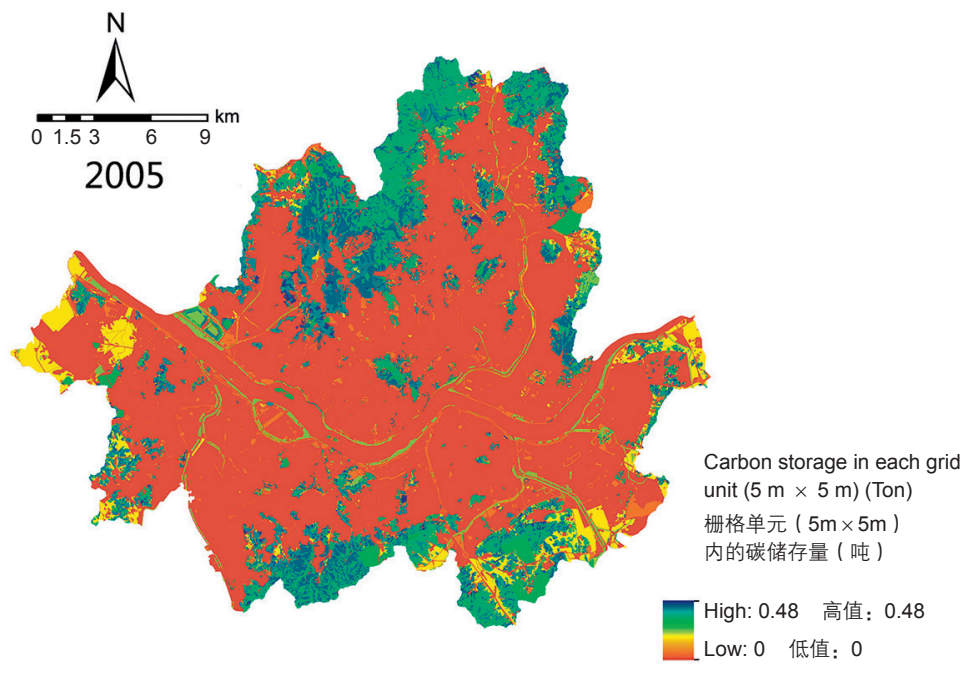

果。统计学的显著性正得分表示为热点, 得分越高表示热点聚集越紧 密; 反之, 负值表示冷点, 得分越低表示冷点聚集越紧密 ${ }^{[24]}$ 。

\section{3 研究结果}

\subsection{5年间绿地面积变化}

2005 2015年间，首尔市各绿地类型的面积变化呈现城市化进程 中典型的生境置换特点, 总绿地面积减少了 $1582.75 \mathrm{hm}^{2}$, 其中农田 面积锐减 $48.78 \%$, 并多转换为建设用地; 景观绿化植栽区面积增加 $26.81 \%$; 大部分其他绿地类型的面积均小幅减少。楿楖林是研究区域 内的优势群落类型, 其总面积比例在 2005 年和 2015 年分别为 $25.86 \%$ 和 $27.25 \%$ ，其次为刺槐林和赤松林（表1，图3）。

\subsection{2015年间绿地碳储存量变化}

经InVEST模型计算后可得出首尔市 2005 年和 2015 年的碳储存总 量数据与碳储存量分布图（图4）。其中，2005年绿地碳储存总量为 263.64 万吨，2015年下降至242.55万吨。碳储存总量的下降可归处于建 设用地的增加以及绿地的减少。尽管景观绿化植栽区的增加可部分弥 补自然生境的丧失，但与自然林相比，其碳储存能力较低。两个年份 的栅格单元 $(5 \mathrm{~m} \times 5 \mathrm{~m})$ 碳储存量最大值约为 0.48 吨, 最小值约为 0.05

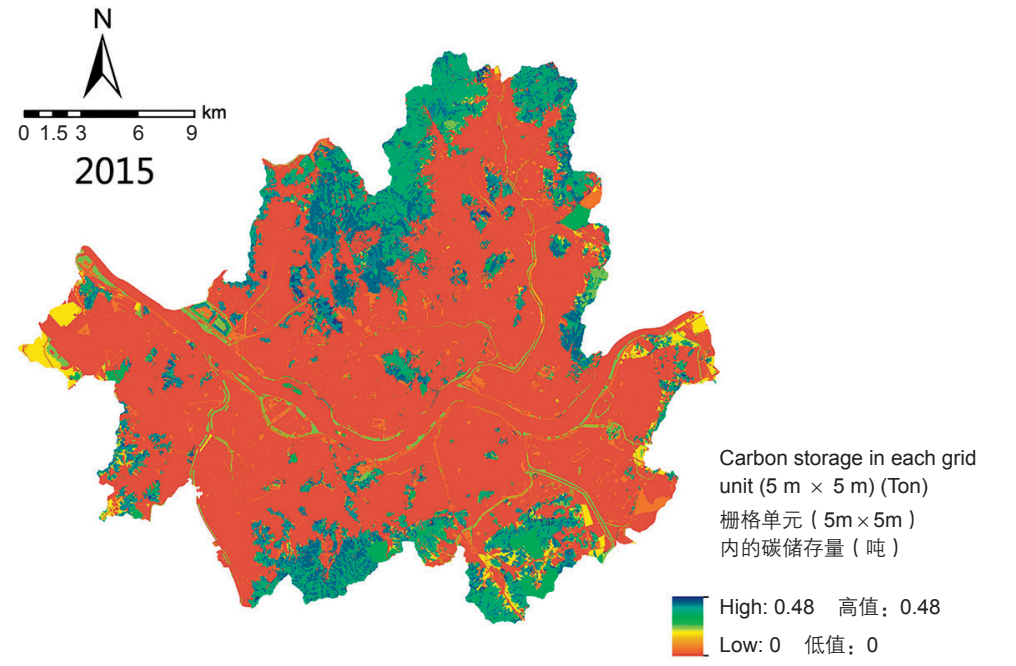

number of sample points, $\bar{X}$ is average deviation, $S$ is standard deviation, and the statistical result $\mathrm{G}_{\mathrm{i}}{ }^{\prime \prime}$ is the score of a sample point. Positive scores represent hotspots, and the larger the score is, the more intensive the clustering of hotspots. Conversely, negative values represent cold spots, and smaller score indicates tighter cluster of cold $\operatorname{spots}^{[24]}$.

\section{Results}

3.1 Area Changes of Green Spaces between 2005 and 2015

Between 2005 and 2015, the area change of each green space type in Seoul showed typical habitat shifts in urbanization. The overall green spaces decreased by $1,582.75 \mathrm{hm}^{2}$. Specifically, the area of farmland decreased sharply by $48.78 \%$, being reoccupied as construction lands; landscape plantation increased by $26.81 \%$; the areas of most other green space types saw a slight decrease. Quercus spp. forests were the dominant community in the study area, the coverage of which increased from $25.86 \%$ to $27.25 \%$ between 2005 and 2015 , followed by Rabinia pseudoacacia forests and Pinus densiflora forests (Table 1 , Fig. 3).

3.2 Carbon Storage Changes of Green Spaces in 2005 and 2015

The results generated by the InVEST model (Fig. 4) show that the total carbon storage of green spaces in Seoul was $2,636,400$ tons in 2005 and 2,425,500 tons in 2015, resulting from the increase of ubran construction and the decline of green spaces in the city. Although the increase in landscape plantation can be regarded as a compensation for the loss of 
吨, 且碳储存量较大的地区分布于首尔市南北部边缘和一些散布的孤 岛状绿地中, 这些区域内包含了碳储存量较大的群落类型。这一空间 分布特征与地形密切相关, 由于这些区域多为山地, 较大的坡度限制 了部分建造活动, 使得碳储存量较大的群落类型得以保留。

\section{3 绿地碳储存量热点分布特征}

热点分析有助于发现空间自相关性区域的聚集特征, 运用热点 分析法计算局部空间的自相关性, 可以探究碳储存热点区域。结果表 明：1）首尔市绿地中热点区域的面积占比从 2005 年的 $48.2 \%$ 上升至 2015年的57.2\%（表2）；2）研究区域内存在4个较大的独立热点地 带, 主要集中在冠岳山、九龙山、北汉山、水落山等首尔市边缘山区 (图1, 5), 这些区域内植被群落类别丰富且涵盖碳储存能力较强的 植被类型, 如赤松林、栎树林和毛叶胡杨林等; 3 ) 强热点 (置信度 99\%）区域的面积占比从2005年的 $36.5 \%$ 略降至2015年的 $36.1 \%$, 但同时 北汉山区域的弱热点（置信度 $90 \%$ ）增长较多（表2, 图5）；4）多个 冷点聚类区域散布在汉江南北两侧高密度建设地带, 大部分为城市公 园 ( 图1，5), 如世界杯公园、汝矣岛和奥林匹克公园等, 这些区域 内的绿地类型多为景观绿化植栽区, 碳储存能力强的植被群落较少; 5 ) 其他绿地内的碳储存密度高值与低值之间的空间自相关性较弱, 显 示随机分布的特点。

结合总体热点分析可以得出, 首尔市内的绿地的碳储存能力呈现 “冷热不均” 的空间特征。其中热点区域可视为碳储存的重点保护区 域，而冷点区域的群落空间配置及群落结构有待修复和优化。

表2: 2005 年和2015年首尔市绿地碳储存能力空间分布热点 Table 2: Hotpots of carbon storage capacity of green spaces in Seoul in 2005 and 2015

\begin{tabular}{c|c|c|c|c}
\hline \multirow{2}{*}{$\begin{array}{c}\text { 级别 } \\
\text { Level }\end{array}$} & \multicolumn{2}{|c|}{2005} & \multicolumn{2}{c}{2015} \\
\cline { 2 - 5 } & $\begin{array}{c}\text { 面积 } \\
\text { Area } \\
\left(\mathrm{hm}^{2}\right)\end{array}$ & $\begin{array}{c}\text { 比例 } \\
\text { Coverage }(\%)\end{array}$ & $\begin{array}{c}\text { 面积 } \\
\text { Area } \\
\left(\mathrm{hm}^{2}\right)\end{array}$ & $\begin{array}{c}\text { 比例 } \\
\text { Coverage (\%) }\end{array}$ \\
\hline $\begin{array}{c}\text { 弱热点 ( 置信度90\%) } \\
\text { Hotspot } \\
90 \% \text { confidence }\end{array}$ & 999.6918 & 4.6 & 653.744 & 3.3 \\
\hline $\begin{array}{c}\text { 中强热点 ( 置信度95\%) } \\
\text { Hotspot } \\
95 \% \text { confidence }\end{array}$ & $1,530.9865$ & 7.1 & $3,543.3469$ & 17.8 \\
\hline $\begin{array}{c}\text { 强热点 ( 置信度99\%) } \\
\text { Hotspot } \\
99 \% \text { confidence }\end{array}$ & $7,830.3065$ & 36.5 & $7,178.9165$ & 36.1 \\
\hline $\begin{array}{c}\text { 总计 } \\
\text { Total }\end{array}$ & $\mathbf{1 0 , 3 6 0 . 9 8}$ & $\mathbf{4 8 . 2}$ & $\mathbf{1 1 , 3 7 6 . 0 1}$ & $\mathbf{5 7 . 2}$ \\
\hline
\end{tabular}

natural habitats, its carbon storage capacity is lower than that of most natural forests and has less contributed to the city's total carbon storage. The carbon storage distribution maps reveal that the maximum carbon storage per grid unit $(5 \mathrm{~m} \times 5 \mathrm{~m})$ is 0.48 ton, while the minimum carbon storage is 0.05 ton. The areas with the largest amount of carbon storage are identified at the margins in the north and south of Seoul and island-like green spaces, where vegetation communities with large carbon storage capacity dominate. Due to the mountainous topography that limits urban construction, local vegetation communities are well remained.

\subsection{Carbon Storage Hotspot Distribution Pattern of Green Spaces}

Examining hotspot distribution pattern helps analyze aggregation characteristics of spatial autocorrelation. This research approaches the carbon storage hotspot distribution of the study area. Results indicate that: 1) Hotspots of green spaces in Seoul increased from $48.2 \%$ in 2005 to $57.2 \%$ in 2015 (Table 2); 2) Four large isolated hotspots in the study area (Fig. 1, 5) are found in the mountainous margins of Seoul, including Gwanaksan Mountain, Guryongsan Mountain, Bukhansan Mountain, and Suraksan Mountain, where vegetation communities enjoy a high diversity and carbon storage capacity, such as Pinus densiflora forests, Quercus spp. forests, and Populus tomentiglandulosa forest; 3) The area of $99 \%$-confidence hotspot decreased slightly from $36.5 \%$ (2005) to $36.1 \%$ (2015), meanwhile the area of 90\%-confidence hotspot in the Bukhansan Mountain increased a lot during the examining period (Table 2, Fig. 5); 4) A number of cold spots are scattered throughout high-density construction areas on both sides of the Han River, and most of them are urban parks (Fig. 1, 5), such as the World Cup Park, Yeoeuido Park, and Olympic Park, where landscape plantation dominates and vegetation communities with high carbon storage capacity are in shortage; 5) For other green spaces, the spatial autocorrelations between high and low density of carbon storage are not significant, showing random distribution patterns.

Overall, both the hotspots and cold spots of green space carbon storage show an uneven distribution pattern. The hotspots should be given a protection priority for their great carbon storage capacity, while the spatial and vegetation structure of the cold spots need restoration and reorganization in the future.

\section{Conclusion and Discussion}

\subsection{Conclusion}

The emission of greenhouse gases like carbon dioxide is the main cause of climate change ${ }^{[25]}$. Green spaces play an important 
Hotspot distribution maps of carbon storage in 2005 and 2015

\section{4 结论与讨论}

\section{1 结论}

二氧化碳作为主要的温室气体, 是气候变化的主要动因 ${ }^{[25]}$ 。因 此, 绿地捕获和储存大气碳的潜力对于缓解全球变暖起着重要作用 ${ }^{[26]}$ 。 本研究以韩国首尔市为例, 基于当地政府提供的高精度生境数据分析 了2005年和 2015 年当地多种绿地类型的碳储存能力强弱及空间分布特 点, 并进行了对比分析。本研究的主要发现包括:

1 ） 2005 2015年间，研究区域内总绿地面积减少了 $1582.75 \mathrm{hm}^{2}$, 其中农田面积锐减 $48.78 \%$ ，同时景观绿化植栽区增加了 $26.81 \%$ 。柇树 林是研究区域内的优势群落类型, 所占比例由 2005 年的 $25.86 \%$ 提升至 2015 年的 $27.25 \%$ 。

2 ） 2005 年首尔市绿地碳储存总量为 263.64 万吨，2015年下降至 242.55 万吨。两个年份的栅格单元 $(5 \mathrm{~m} \times 5 \mathrm{~m})$ 碳储存量最大值约为 0.48 吨, 最小值约为 0.05 吨, 且碳储存量较大的地区均分布在首尔市南北部 边缘和一些散布的孤岛状绿地中。

3 ） 2005 年，首尔市绿地总面积的 $48.2 \%$ 属于碳储存热点区域，至 2015年热点区域面积上升至 $57.2 \%$ ，其中，强热点区域面积占比略下降 了 $0.04 \%$, 多个冷点聚类区域散布在汉江南北两侧的高密度建设地带。 区内整体呈现 “冷热不均” 的空间特征。 role in capturing and storing atmospheric carbon ${ }^{[26]}$. Focusing on the city of Seoul, this research compares the carbon storage capacities of varied green space types and the distribution patterns of carbon storage in 2005 and 2015, based on highsolution habitat data provided by the government. Main research findings include:

1) From 2005 to 2015, the total area of green spaces in Seoul decreased by $1,582.75 \mathrm{hm}^{2}$, of which farmland decreased sharply by $48.78 \%$ while landscape plantation increasing by $26.81 \%$. Quercus spp. forest is the dominant community type in the study area with a coverage of $25.86 \%$ in 2005 and $27.25 \%$ in 2015 .

2) In 2005 , the total carbon storage capacity of green spaces in Seoul was 2,636,400 tons, which fell to 2,425,500 tons in 2015. In both years, the maximum carbon storage per grid unit $(5 \mathrm{~m} \times 5 \mathrm{~m})$ was about 0.48 ton while the minimum was about 0.05 ton. The largest amount of carbon storage was distributed in the margin zones to the north and south of Seoul and island-like green spaces.

3) In 2005, the carbon storage hotspots covered $48.2 \%$ of the total green spaces in Seoul. By 2015, the figure rose to $57.2 \%$. Specifically, the area of $99 \%$-confidence hotspot fell slightly by $0.04 \%$; a number of cold spots are identified in the high-density construction zones on both sides of the Han River; and the overall distribution pattern of carbon storage hotpots and cold pots in Seoul is uneven.
Hotspot $-99 \%$ confidence 强热点（置信度 $99 \%$ )

Hotspot - $95 \%$ confidenc 中强热点 ( 置信度 $95 \%$ ) Hotspot - $90 \%$ confidence 弱热点（置信度 $90 \%$ )

Cold spot - $99 \%$ confidence 冷点 (置信度 $99 \%$ )

Cold spot $-95 \%$ confidence 冷点（置信度 $95 \%$ )

Cold spot $-90 \%$ confidence 冷点（置信度 $90 \%$ ） Not significan 不显著
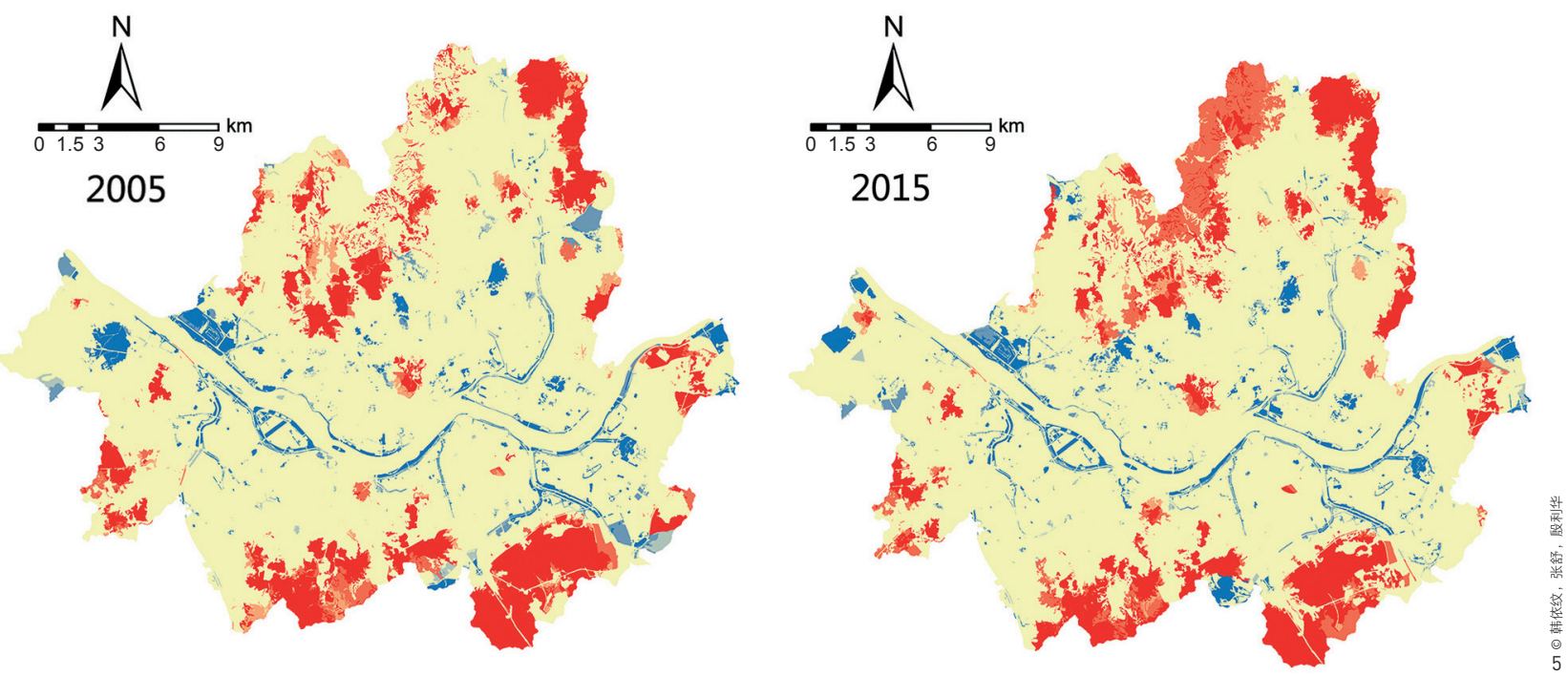
以上结果表明, 相较于人工建造绿地, 自然/半自然绿地的碳储存 能力更强, 因此在城市发展过程中应对自然/半自然绿地的保护和修复 予以高度重视。同时, 作为自然绿地的有效补充, 人工建造绿地也发 挥了重要的生态系统功能。

\section{2 讨论}

城市化进程中碳足迹的增加, 以及吸纳其产生的二氧化碳所需的 自然生境的减少已成为生态赤字和城市环境问题的主要原因 ${ }^{[4]}$ 。绿地作 为主要的城市生境类型, 是维持城市生物多样性和生态系统服务功能 的重要载体, 而运用遥感工具、模型模拟、空间分析等技术手段对绿 地生态系统服务进行评估是城市规划设计及管理实践的基础。根据本 研究结果, 笔者提出以下建议:

首先, 加强对绿地生态系统服务功能的重视。本研究以碳储存量 为指标, 在对首尔市2005 2015年间绿地碳储存能力进行评估后发现, 总绿地面积及碳储存总量呈下降趋势。当前首尔市政府制定的绿地政 策侧重于增加绿地数量、提升其空间质量, 并强调增强绿地生态系统 服务功能是应对气候变化和打造低碳城市的重点。绿地的植被群落特 征和空间分布决定了城市区域碳储存能力。因此, 保护绿地内固碳能 力较强的植被类型并优化此类植被的空间布局, 对于稳固城市用地固 碳能力及减少碳储存量损失有重要意义 ${ }^{[1]}$ 。

其次, 优化绿地修复保护与绿色基础设施规划策略。尽管绿地对 降低大气碳含量的贡献有限, 但与发展其他替代能源相比, 高效的城 市绿地规划和管理策略仍可作为减缓气候变化、节约环保成本的有效 方法之一 ${ }^{[1][4]}$ 。例如, 发掘和利用潜在种植空间、减少城市硬质地面, 以及在保持多龄乔木结构的同时提升乔灌草多层种植方式, 均可增加 单位面积的碳储存量并优化其碳储存能力。

本研究不仅可以为首尔市及其他类似区域的生态保护实践和可持 续土地规划与管理提供科学依据, 也可以为中国城市生态系统服务功
This study shows that carbon storage capacity of natural / seminatural green spaces is higher than that of constructed green spaces. The protection and restoration of natural green spaces should be highly promoted in urban development. At the same time, constructed green spaces, as a supplement to natural green spaces, has also played an important role in maintaining ecosystem health.

\subsection{Discussion}

The increasing carbon footprint in the process of urbanization and the reduction of natural habitats that capture and store carbon dioxide together become a main cause of ecological deficits and urban environmental problems ${ }^{[4]}$. As significant habitats in cities, green spaces are important in maintaining urban biodiversity and delivering ecosystem services. The usage of remote sensing tools, modeling simulation, spatial analysis, and other technical means to evaluate ecosystem services of green spaces is the basis of urban planning, design, and management practice. According to the results of this study, here suggestions on future research and practice are put forward:

First, research on the ecosystem services of green spaces needs to be strengthened. Focusing on measuring carbon storage capacity, this research finds that the total area and the total carbon storage capacity of green spaces show a downward trend from 2005 to 2015. Recognizing that enhancing ecosystem services of green spaces is key to responding to climate change and building a low-carbon city, the current green space policies were introduced by the Seoul Metropolitan Government to increase green space coverage and improve its quality. Urban carbon storage is defined by the vegetation community characteristics and distribution patterns of green spaces. It means that protecting vegetations with strong carbon sequestration capacity and optimizing their spatial patterns are important to maintaining a city's carbon sequestration capacity and reducing carbon storage losses ${ }^{[1]}$.

Secondly, improving green space restoration and green infrastructure planning is expected. Compared with exploring alternative energy sources, green spaces less contribute to reduction of atmospheric carbon, but it is proven that efficient urban green space planning and management can mitigate climate change and save costs on environmental improvement ${ }^{[1][4]}$. For example, urban carbon storage density and capacity can be improved by exploring potential planting spaces, reducing impervious surfaces, protecting perennial trees, and enriching vegetation community structures and layers.

This study not only provides a scientific basis for ecological protection practices and sustainable land planning and 
能评估和绿地更新策略的制定提供借鉴方法。相较于传统的基于实地 测量的方法, 基于官方数据库平台的研究能够更加快速便捷地计算出 绿地固碳量 ${ }^{[27]}$, 同时, 基于同一平台的电子化数据可衔接不同尺度的 评估结果。此类数据平台的建立需要政府推动。首尔市是全球领先的 数字化城市, 其城市数据的采集、发布和管理方式值得中国借鉴。然 而, 受限于InVEST模型模拟中各类绿地碳密度数据的不足, 本研究只 能参考各地相关研究进行间接评估。今后，相关研究应注重新技术的引 人，鼓励和推动对绿地生态系统服务进行多尺度、多指标的评估。 management in Seoul and other similar regions, but also offers a reference for urban ecosystem service assessment and green space renewal strategy development in China. Different from traditional on-site measurement methods, this research is based on the access of official database, which allows for a more convenient and efficient estimation of the carbon storage capacity of green spaces ${ }^{[27]}$ across scales. The establishment of such a data platform requires government supports. Seoul is one of the world's leading digital cities in collecting, publishing, and managing urban data. However, given the limited carbon density data of various green spaces, authors have to adopt relevant research as a reference for the modeling stmulation. Future research is expected to introduce new technologies to promote multi-scaled and indexical assessments of ecosystem services of green spaces. LAF

\section{REFERENCES}

[1] Jo, H. (2002). Impacts of urban greenspace on offsetting carbon emissions for middle Korea. Journal of Environmental Management, 64(2), 115-126.

[2] Wang, B. Z., Wang, C. X., He, P., \& Shen, S. Y. (2004). Review on urban greenland study. Urban Planning Forum, (2), 62-68.

[3] Han, Y. W., \& Dai, F. (2018). Review of Study on Ecosystem Services Function of Urban Green Spaces: Indicators, Methods and Assessment Framework. Chinese Landscape Architecture, 34(10), P55-60.

[4] Liu, M. C. (2016). The ecological security pattern of China's energy consumption based on carbon footprint. Landscape Architecture Frontiers, 4(5), 10-17.

[5] Oubrahim, H., Boulmane, M., Bakker, M. R., Augusto, L., \& Halim, M. (2015). Carbon storage in degraded cork oak (Quercus suber) forests on flat lowlands in Morocco. IForestBiogeosciences and Forestry, 9(1), 125-137.

[6] Zhang, J. Q., Su, Y. Q., Kang, Y. X., Xu, X. M., \& Qin, L. (2009). Carbon sequestration of young Robinia pseudoacacia plantation in Loess Plateau. Chinese Journal of Applied Ecology, 20(12), 2911-2916.

[7] Wang, L. (2013). Carbon sequestration capacity of common trees and communities in the downtown of Chongqing (Master's thesis, Southwest University). Retrieved from http:/ cdmd.cnki.com.cn/Article/CDMD-10635-1013268190.htm

[8] Han, Y. W., Kang, W. M., \& Song, Y. (2018). Mapping and Quantifying Variations in Ecosystem Services of Urban Green Spaces: A Test Case of Carbon Sequestration at the District Scale for Seoul, Korea (1975-2015). International Review for Spatial Planning and Sustainable Development, 6(3), 110-120.

[9] He, C. Y., Zhang, D., Huang, Q. X., \& Zhao, Y. Y. (2016). Assessing the potential impacts of urban expansion on regional carbon storage by linking the LUSD-urban an InVEST models. Environmental Modelling and Software, 75/C $44-58$

[10] Hu, S., Zhang, X. R., \& Guan, D. J. (2018). Analysis on carbon storage change of construction land expansion in chongqing based on InVEST model. Research of Soil and Water Conservation, 25(3), 323-331.

[11] Davies, Z. G., Edmondson, J. L., Heinemeyer, A., Leake, J. R., \& Gaston, K. J. (2011). Mapping an urban ecosystem service: Quantifying above-ground carbon storage at a city-wide scale. Journal of Applied Ecology, 48(5), 1125-1134.

[12] Mcpherson, E. G. (1998). Atmospheric carbon dioxide reduction by Sacramento's urban forest. Journal of Arboriculture, 24(4).

[13] Lee, G, Lee, H., \& Lee, J. (2015). Greenhouse gas emission reduction effect in the transportation sector by urban agriculture in Seoul, Korea. Landscape and Urban Planning, $140,1-7$.

[14] Seoul Metropolitan Government. (2016). Seoul Urba Planning. Retrieved from http://www.seoul.go.kr

[15] Sharp, R., Chaplin-Kramer, R., Wood, S., Guerry, A., Tallis, H., \& Ricketts, T. (2014). InVEST user's guide. Natural Capital Project, Stanford Uiversity. Retrieved from http://data. naturalcapitalproject.org/nightly-build/invest-users-guide/ natural

[16] Wang, S. Q., Zhou, C. H., Li, K. R., Zhu, S. L., \& Huang, F. H. (2000). Analysis on spatial distribution characteristics of soil organic carbon reservoir in China. Acta Geographica Sinica, 55(5), 533-544.

[17] Li, T. J., Ren, B., Wang, D. H., \& Liu, G. B. (2015). Spatial variation in the storages and age-related dynamics of forest carbon sequestration in different climate zones-evidence from black locust plantations on the loess plateau of China. Plos One, 10(3).

[18] Cheng, X. Q., Han, H. R., \& Kang, F. F. (2012). Biomass, carbon accumulation, and its partitioning of a Pinus tabulaeformis plantation ecosystem in Shanxi Province, China. Chinese Journal of Ecology, 31(10), 2455-2460.

[19] Xing, S. J., Du, L. M., Zhai, J. P., Zhou, J., \& Yang, Q. S. (2009).
Carbon sequestration effects of artificial forest in the Yellow River Delta. Journal of Shandong Forestry Science and Technology, 39(3), 5-8.

[20] Zhiyanski, M., \& Glushkova, M. (2013). Carbon storage in selected European chestnut (Castanea sativa Mill.) ecosystems in Belasitsa Mountain, SW Bulgaria. Silva Balcanica, 14(1), 60-75

[21] Kim, Y., Yi, M., \& Lee, Y. (2009). Estimation of carbon storage, carbon inputs, and soil $\mathrm{CO}_{2}$ efflux of alder plantations on granite soil in central Korea: comparison with Japanese larch granite soil in central Korea: comparison with Japanese larch
plantation. Landscape and Ecological Engineering, 5(2), 167.

[22] Yi, F. (2017). Study on forest carbon density and spatial distribution pattern of Taiyue Mountain in Shanxi Province. Journal of Shanxi Agricultural Sciences, 45(111), 1814-1817.

[23] Anselin, L. (1995). Local Indicators of Spatial Association LISA. Geographical Analysis, 27(2), 93-115.

[24] Yang, X. M., Dai, X. J., Tian, S. Q., \& Zhu, G. P. (2014). Hot spot analysis and spatial heterogeneity of skipjack tuna (Katsuwonus pelamis) purse seine resources in the western and central Pacific Ocean. Acta Ecologica Sinica, 34(13), 3771 and centr.
3778.

[25] Jo, H. (2002). Impacts of urban greenspace on offsetting carbon emissions for middle Korea. Journal of Environmental Management, 64(2), 115-126.

[26] Darren, D .S., Petruccelli, D., Patton, S. J., Winemaker, M., \& Beer, J. D. (2016). From "surgical gatekeepers" to "patient navigators": examining perceptions and practices of hip and knee osteoarthritis management among primary healthcare knee osteoarthritis management among primary health

[27] Ji, Y. Y., Genovese, P. V., \& Wang, T. (2016). Development and significance of carbon sequestration calculation system of green plants in urban space. Chinese Landscape Architecture, (8), 31-35. 